\title{
Poverty, Public Assistance and Single Mothers:
}

- A Comparative Look at Norway, Russia and the U.S. 


\begin{abstract}
This article presents some of the perceptions and experiences of mothers on public assistance and their social workers in three countries-Norway, Russia and the US.

Based on in-depth interviews in each country with social workers and the women, five themes emerged that will be presented here. The mothers spoke of the inadequacy of economic support to meet their needs, a life of poverty that sometimes involved discrimination of them as mothers, and a loss of hope that their lives could be different. Two themes that stood out in the interviews with social workers was the lack of resources needed to help their clients and the dilemma faced as an agent of social welfare institutions balanced with being an advocate for the mothers' needs. In spite of differing socio-economic and cultural contexts, there is surprising similarity in both the mothers' and social workers' experiences. An expected finding was the level of destitution for mothers in the US and Russia compared to Norway where mothers spoke less about basic economic need. All of the social workers felt hampered by the bureaucracies where they worked and the social welfare regulations. They found different ways to cope with this. More differences are noted among social workers' perceptions and experiences within than between countries.
\end{abstract}

\title{
Key Words
}

Social Work Single Mothers Lone Parents Public Assistance Norway Russia United States

Comparative Research

\section{Introduction}

In fall 2000, Professors Rolf Lyngstad and Siv Oltedal, faculty in the Department of Social Work at Bodø Regional University, were awarded funding from the Norwegian Research Council for a three-year study on the Legitimisation of Professional Social Work in a Comparative Perspective. The broader goal of the Legitimization project was to recognize how professional social work practice is understood and rendered legitimate in five countries: Canada, Australia, Norway, Russia and the United States. The project's significance was twofold, (1) to discover the impact that different socio-political systems exert on social workers and their clients, and (2) to enhance our experience in conducting comparative research.

There were two phases to the study that began in October 2003 and concluded at the end of 2006. The research question in the first phase was "How do professional social workers within different educational and professional contexts and different welfare systems legitimate their work?" (Hutchinson 2001). Secondary sources were used to provide an overview of the welfare system, the social work profession and poverty in each country. Areas included were the history of the profession, educational framework and curriculum, legal and ethical mandates, legislation related to poverty (e.g. housing, health care, public assistance) demographics on families, welfare services, and so on (Hutchinson, et.al., 2001).

The purpose of the second phase of the study (Lyngstad 2004) was to shed light on how professional social workers and their clients, mothers on public assistance, experience being a part of the social welfare systems. We wanted to explore the relationship between the social worker and her client and how this might be affected by socio-political and institutional structures and policies.

This article is based on the second phase of the project and takes a closer look at three of the countries: Norway, Russia and the U.S. To begin, I will give a brief summary of the social welfare systems, formula for establishing poverty, and a snapshot of demographics of single mothers and the role of social workers. A description of the sample and methodology of the study is provided, followed by a presentation of the findings organized by themes. I will conclude by considering some possible implications that might shed light on the impact of 
the different welfare systems on mothers and their children, and the social workers that try to help them.

\section{Welfare Mothers' Voices}

In the United States, there has been considerable research done on public assistance and welfare mothers, but little research done that describes the perspectives and experiences of the single mothers themselves. Some examples of studies where women's voices are the dominant source of information include McIntyre's work in Canada with welfare mothers who are poor where she explored their "inner life" (2003). Edin and Lein (1997) published findings from extensive conversations with more than 300 women in four different cities in the US. Seccombe et al. (1998) set out to document the occurrence of food insecurity among single mothers who were poor, and in 2007 did another study on welfare recipients' thoughts about the new federal welfare reform (Seccombe et al.). In "So You Think I Drive a Cadillac?": Welfare Recipients' Perspectives on the System and Its Reform, Seccombe (1999) conducted in-depth interviews with 47 women about their experiences of being on welfare. In response to the PRWORA legislation that created TANF, Scarbrough (2001) talked with welfare mothers who were college students to find what "personal responsibility" meant to them. Special issues of Affilia: Journal of Women in Social Work in 2000 and Journal of Social Issues in 2001 were devoted to poor women and welfare where some of the studies explored how mothers felt being involved with the social welfare system (Brandwein \& Filiano 2000; Nicolas \& JeanBaptiste 2001; Perlmutter \& Bartle 2000; Scarbrough 2001; Tickameyer et al. 2000). McPhee and Bronstein (2003) interviewed 39 current and former welfare recipients who shared largely negative experiences, an outcome in all of these studies. This author knows of no other crossnational research on the "inner" experiences of women on welfare. Millar and Rowlingson (2001) edited a book on how policy changes in different countries affect single parents, but their goal was not to compare the personal experiences of welfare-dependent mothers.

There are some common themes voiced by welfare mothers' that stood out in the more indepth studies, as well as surveys. First was a sense of deprivation due to insufficient economic support and overall lack of resources to meet basic needs such as childcare, health care, housing, and living wage job options (Corcoran et al. 2000; DeParle 2005; Edin \& Lein 1997; Harper 2001; Lindhorst \& Mancoske 2006; McIntyre, et al. 2003; McPhee \& Bronstein 2003; Scarbrough 2001; Seccombe 2007; Seccombe et al. 1998; Tickamyer et al. 2000). Another frequently mentioned experience was the lack of respect by either by the caseworker or the welfare system itself. Women talked of feeling "degraded," a "personal humiliation," "stigmatized," and "treated like dirt" (Pearlmutter \& Bartle 2000; Brandwein \& Filiano 2000; McIntyre, et al. 2003; McPhee \& Bronstein 2003). Tickamyer et al. (2000) presented welfare participants' perceptions of the welfare system against a backdrop of the "rational" network of policies and services and found that "Women frequently find themselves in conflict with the operation of the agencies that are supposed to help them..." (187). A third theme that stands out is that in spite of sometimes ambitious goals, the women have "grim speculations about the future" (McPhee \& Bronstein 2003; Tickamyer et al. 2000).

Feeling exhausted, like a "failed mother" and not having a life of their own was expressed by many mothers (Baker \& Tippen 2002; Harper 2001; Jennings 2004; Seccombe, 1999). While there are limited opportunities for work, mothers who do get jobs worry about the lack of support when their child is sick. Most women spoke of having limited choices in all aspects of their lives. This deficit of resources available for clients presents their caseworkers with a frequently impossible task, i.e. to get them a job and off of welfare.

When the women were asked about the positive aspects of welfare support, they said that it kept them from being homeless or in a shelter, and the aid enabled them to leave an abusive situation (Seccombe 2007, 1999). Some women have been able to find work at a livable wage 
with enough support for childcare and health insurance (Scott 2006), but these were clearly the exception. The women who found work or who received support to complete a degree or vocational study of their choosing saw welfare as a way out of poverty, but these experiences were more in relation to a fortunate outcome than being on welfare.

\section{Welfare, Poverty and Single Mothers}

Welfare systems

The policies and programs that constitute the social welfare system are created from different histories and philosophies that explain how society should be organized to meet human need (Esping-Andersen 1990). Welfare systems were designed to support human potential and wellbeing, and in times of hardship, provide care for those most affected by changes in natural, economic and social environments. All three locations for this study-Saratov, Nordland and Humboldt-- are the administrative centers for their regions. While Saratov is an urban city, Nordland and Humboldt are more rural. The participants in this study are affected by social welfare legislation at the national, state and county levels. Table 1 briefly summarizes some of the characteristics of the social welfare systems in each country at the national level. Norway's welfare system is directed toward a redistribution of resources and a reduction or elimination of poverty. This is not the case in the USA or Russia.

\section{United States}

The social welfare system in the United States is residual, based on selective, individualistic and positivist philosophies (Kohlert 1989; Wilensky \& Lebeau1958.). Values inherent in the welfare programs for the poor are competition, progress and economic success. The assumption is that the individual is responsible for meeting their basic needs and any public intervention or responsibility must occur after all other systems have failed (e.g. family, marketplace). Social welfare policies and programs in the US have a history of being punitive with mothers for being poor (Abramovitz 1988; Gordon 1994, 1988; Rainford 2004). Cash aid, food stamps and public health care assistance for families was originally an entitlement program enacted as a part of the 1935 Social Security Act and known as Aid to Families with Dependent Children (AFDC). AFDC as an entitlement was dismantled in 1996 when the Personal Responsibility and Work Opportunity Reconciliation Act (PRWORA) passed in Congress. PRWORA ended the federal entitlement to cash assistance and was replaced by TANF (Temporary Assistance to Needy Families). TANF legislation gave states considerable flexibility to design public assistance programs. All states chose to continue cash aid to parents and their children, but under TANF the funding would be in the form of block grants rather than open-ended funding based on need. Programs are means-tested, time limited and work is required as a condition of receiving assistance. The objective of TANF is to reduce the welfare rolls, i.e. get mothers off of aid. Many of the regulations are punitive; for example, there is a 5-year lifetime limit and a 2-year consecutive limit. If states goals (e.g. reduced caseloads, percentage of parents meeting work requirements) are not reached, federal funding to states is reduced. Some policies are set by states (e.g. grant amount, work hours mandated, length of time allowed on grant) and county governments have flexibility in setting other policies (e.g. what qualifies as work, acceptable educational plans, reduced parent aid and incarceration in school truancy situations). In contrast to most European countries where mothers are not expected to prepare for work until their child is twelve years old or work until the child reaches sixteen years old (Baker 2002; Millar 2001), some states require a mother to begin meeting the work requirement when her child turns three months.

California's version of TANF is called California Work Opportunity and Responsibility to Kids (CalWORKS). California chose to place emphasis on preparing parents to work, which most states did. Waivers for the work requirement are possible in some cases where domestic violence, mental health or chemical dependency issues need to be addressed before a parent is work-ready. If a state or county unemployment rate exceeds a certain level, waivers can be 
requested regarding caseload reduction requirements. Social welfare programs are based on the belief that everyone can find a job to earn enough to provide economically for their family. The idea that some people are more deserving than others remains a central aspect. For example, monthly grant amounts for developmentally disabled and foster parents are funded more generously than grants for single mothers. Other needs such as higher education, health care, childcare and housing remain at the whims of the marketplace. The social welfare network consists of a significant non-governmental organization (NGO) component, both nonprofit and for-profit, many which the government has contracts with for providing work training, counseling and childcare.

Table 1: Welfare systems

\begin{tabular}{|c|c|c|c|c|c|}
\hline Country & $\begin{array}{l}\text { Political/Econ } \\
\text { system }\end{array}$ & Minimum wage & $\begin{array}{l}\text { Policy on what } \\
\text { is poverty }\end{array}$ & $\%$ in poverty* & $\begin{array}{l}\text { Policy on social } \\
\text { welfare benefits }\end{array}$ \\
\hline $\begin{array}{l}\text { Norway } \\
4.5 \text { million } \\
\text { Nordland: } \\
239,109\end{array}$ & $\begin{array}{l}\text { Social } \\
\text { democracy; } \\
\text { strong } \\
\text { safety net; } \\
\text { institutional } \\
\text { welfare policy }\end{array}$ & $\begin{array}{l}\text { Not decided by } \\
\text { the government } \\
\text { but the unions } \\
\text { for employers } \\
\text { and employees } \\
\text { and concerns } \\
\text { people who } \\
\text { are organized. } \\
\text { Wages Nkr } 118 \\
\text { (approx } \$ 16 \text { )/ } \\
\text { hr unskilled. } \\
\text { Nkr } 132 / \text { hour } \\
\text { skilled }\end{array}$ & $\begin{array}{l}\text { Relative: } \\
\text { family that } \\
\text { over a 5-year } \\
\text { period has a } \\
\text { cumulative } \\
\text { income, after } \\
\text { tax, lower } \\
\text { than half of } \\
\text { the median } \\
\text { income of the } \\
\text { population; } \\
\text { approx 50\% of } \\
\text { median income }\end{array}$ & $2.1 \%$ & $\begin{array}{l}\text { National } \\
\text { Insurance } \\
\text { Scheme } \\
\text { (universal): no } \\
\text { time limit } \\
\\
\text { Social Care } \\
\text { Act (SWO) } \\
\text { assessed often. } \\
\text { Administrated } \\
\text { by the local } \\
\text { councils with } \\
\text { considerable } \\
\text { variation. }\end{array}$ \\
\hline $\begin{array}{l}\text { Russia } \\
146.9 \text { million } \\
\text { Saratov: } \\
2.7 \text { million }\end{array}$ & $\begin{array}{l}\text { Market-based } \\
\text { economy; } \\
\text { minimal } \\
\text { safety net; } \\
\text { mix residual } \\
\text { \& institutional } \\
\text { welfare policy }\end{array}$ & $\begin{array}{l}\text { Yes. Does not } \\
\text { meet basic } \\
\text { needs, } 20 \% \\
\text { of "survival } \\
\text { income" }\end{array}$ & $\begin{array}{l}\text { Absolute: } \\
\text { Based on food } \\
\text { basket that } \\
\text { guarantees an } \\
\text { appropriate \# of } \\
\text { calories/day \& } \\
\text { a composition } \\
\text { of nutrition that } \\
\text { corresponds } \\
\text { to WHO and } \\
\text { FAO** }\end{array}$ & $\begin{array}{l}36.7 \% \\
40 \% \text { of single } \\
\text { mothers }\end{array}$ & $\begin{array}{l}\text { Social Services } \\
\text { Federal Law of } \\
1995 ; \text { means } \\
\text { tested with no } \\
\text { overall time } \\
\text { limit; one-time } \\
\text { allowance for } \\
\text { pregnancy, } \\
\text { child birth and } \\
\text { parenting until } \\
\text { child is } 1-1 / 2 \\
\text { yrs }\end{array}$ \\
\hline $\begin{array}{l}\text { US } \\
281 \text { million } \\
\text { Humboldt: } \\
128,000\end{array}$ & $\begin{array}{l}\text { Market-based } \\
\text { economy; } \\
\text { minimal } \\
\text { safety net; } \\
\text { mix residual } \\
\text { \& institutional } \\
\text { welfare policy }\end{array}$ & $\begin{array}{l}\text { Yes, annual } \\
\text { income at } \\
\text { minimum wage } \\
\text { is below the } \\
\text { poverty line*** }\end{array}$ & $\begin{array}{l}\text { Absolute: } \\
\text { Based on cost } \\
\text { for food at } \\
\text { subsistence } \\
\text { level as } 1 / 3 \text { of a } \\
\text { family's budget; } \\
\text { established in } \\
1955 \text {; approx. } \\
44 \% \text { of median } \\
\text { income. }\end{array}$ & $12.7 \%$ & $\begin{array}{l}\text { Temporary } \\
\text { Assistance to } \\
\text { Need Families } \\
\text { (TANF); means } \\
\text { tested; } 5 \\
\text { year lifetime } \\
\text { limit; } 2 \text { year } \\
\text { consecutive } \\
\text { limit }\end{array}$ \\
\hline
\end{tabular}

Source: Hutchinson et al. (eds.) (2001)

* 2000 statistics

${ }^{*} \mathrm{FAO}=$ Food and Agriculture of the United Nations, WHO=World Health Organization 


\section{Russia}

In Russia, the political and economic transition has had a significant impact on peoples' overall well being. "The welfare state here [Central and Eastern Europe] contains a lot of various components. Deficit of resources, general social economic crisis in the country, hinders the development of welfare state. Since the policy-makers began a transition to a more market-based economic system the most acceptable way became the tendency to residual social assistance model of means-tested benefits, which is the easiest way but is not the best one for a number of unprotected people" (larskaia-Smirnova, 2001:183). This is a shift in commitment to peoples' welfare, from being a state obligation to a less secure safety net and a growing dependence on NGOs. There remain some policies that are universal in intent: health care, childcare, old age and disability security - but the lack of resources results in few people actually receiving these. The Russian industry continues to provide some benefits - paid vacation, rest houses, sickness benefits and bonuses_but to a much lesser degree than prior to the political changes. The mix of residual and institutional is due, in part, to the Soviet times when all services were free of charge; there are now trends to change this. While higher education (e.g. technical schools and universities) remains tuition-free, health care is increasingly tied to insurance and services available only for a fee.

The Social Service Federal Law of 1995 is the main legislation set at the national level, administered by municipalities. According to the Law of 1995, "Social service is an activity of social service agencies providing social support, everyday household support, socialmedical, psychological-pedagogical, social-juridical services and material help, providing social adaptation and rehabilitation of citizens in a difficult life situation" (Iarskaia-Smirnova and Romanov 2004:173). As it is written in Saratov district, "The neediness of a family and an individual living alone is defined by the social protection bodies at the place of residence in accordance with the Federal Law on the State Social Assistance" (Iarskaia-Smirnova and Romanov 2004: 225). Responsibility to set norms for people's welfare resides at the local level. Similar to the US, social assistance has been decentralized from the political center to regional and municipal authorities which have the authority to determine size and form of assistance; this depends on the financial resources of the region. Like the US, "nuzhdaemost" (neediness) is assessed through an application process. In decisions about the distribution of resources, workers face vague guidelines, where assessments are as much influenced by old Soviet traditions and personal networks as any formal regulations (larskaia-Smirnova and Romanov 2004:220).

\section{Norway}

The Norwegian welfare system is institutional with universal rights for public assistance. While the US system is market based and Russia is in transition, Norway is a social democracy with the core societal values of universalism, equality and economic redistribution (Hutchinson et al. 2001; van Wormer 1994). Rights are connected to citizenship rather than one's status in the labor market or how much one has paid into the social insurance system. Single parents who lose employment or have no access to income can rely on the National Insurance Scheme, i.e. public assistance for three years; if they continue to need support, they fall under the program mandated by the Social Care Act. Both of these are entitlement programs with unlimited coverage, a tight safety net, strong welfare state, and a focus on reduction of inequality (Lyngstad, et.al., 2004).

Social policies in Norway are inherently family-oriented. There is no work requirement as a condition for receiving aid, although work and education are encouraged. A parent is entitled to a leave from their job following the birth of a child for a year at $80 \%$ pay or 42 weeks at $100 \%$ former income. Higher education and health care are universal rights, and there is no limit on higher education if a welfare-dependent mother wanted a degree that would improve her earning potential. 
Even though there is broad agreement about the social welfare system among the public and elected officials in Norway, there remains a stigma to being on public assistance. It is taboo on the personal level, even though the Norwegian society advocates for a generous, universal set of principles to assure people's well being. "The society has a common value of solidarity, but the division between the public and private sphere of provision for this is very complicated and not settled very clearly at a general level" (Lyngstad, et.al., 2004:48).

\section{Poverty}

Formulas for figuring poverty affect eligibility criteria for public assistance grants and other support programs. The formula is used as a variable in measuring the quality of life in general in a society, as it indicates the number of people that are surviving at subsistence level, i.e. an income level below which a society would not want any person or family to live for an extended period. The US and Russia use an absolute definition of poverty, while Norway uses a relative definition (Table 1).

\section{United States}

In the United States the formula for determining poverty was developed by the Social Security Administration in 1965 based on a formula developed by the Council of Economic Advisors in 1964 that determined a typical family spends one-third of their budget on food (Fisher 1992); using a diet composed of minimal nutritional value with the expectation that a family would only be on assistance temporarily, this dollar amount was multiplied by three to arrive at the poverty line. The formula is no longer accurate, since food now makes up closer to $15 \%$ of a family's budget, and the rising costs of transportation, child care and health insurance have not been figured into the equation (Spade 1994). Congress is aware of how the 1964 formula no longer provides a realistic picture of costs, and several studies and hearings have been held to arrive at a more realistic formula (GAO 1997). The current federal poverty line is approximately $44 \%$ of median income. An adult working full time at minimum wage does not earn enough to meet basic needs nor does it bring them above the federal poverty level (California Budget Project 2007; Danziger \& Gottschalk 1995). According to the U.S. Census Bureau, close to $12.7 \%$ of the population lived below the poverty line in 1998 , the last time population census was taken. One-fifth of all children live in families with incomes below poverty and $35 \%$ of these children have working parents. Minority populations have higher rates of child poverty-33.1\% African American, 33\% Latino. Twelve million children lack health care (Center on Budget and Policy Priorities, 2001; Suppes and Wells, 2003; US Census Bureau, 2001).

\section{Russia}

The Soviet Union did not have an official definition of poverty. The risk of being poor in Russia has increased since state protection programs were decreased during the transformation. Since the collapse of the Soviet Union in 1991, the World Bank and other organizations worked with Russian authorities to determine the extent and type of poverty emerging. Their concept of poverty relates somewhat to that of the US, as it is based on the cost of food that guarantees a subsistence level of caloric and nutritional intake (Ferrer-i-Carbonell \& Van Praag 2001). In 1992, it was determined that a household spends a little over two-thirds of their income on food and basic necessities. "Welfare dependent", i.e. poor, are those whose social benefits, pensions and allowances comprise more than $25 \%$ of the family's budget. Unlike the US, Russia makes some distinctions based on status; for example the costs differ for pensioners and adults of working age. Almost $90 \%$ of poor families do not get any social assistance (larskaia-Smirnova and Romanov 2004). 


\section{Norway}

The Norwegian government uses a relative definition of poverty or, as it is termed there, "low income". Since public programs are built on a foundation of universal care, policies about poverty or low income are focused on a reduction of inequality, the well being of the total population, and the distribution of resources; this contrasts with the focus in the US and Russia where the emphasis is on helping as little as possible, i.e. less eligibility and reduction of welfare rolls. Poverty as a concept has entered the public debate again after several decades. Norway's definition of poverty is "....understood as such a low income over time, possibly combined with high necessary expenses due to illness, disability, etc. that people live in a situation where their basic needs are not met...measured as living on an income lower than 50\% of the median income for three years" (St.meld.nr.6, 2002-2003 as referenced in Lyngstad et al. 2004). This relative definition of poverty places Norway's poverty rate at $2.1 \%$ of the population (Hutchinson et al. 2001).

\section{Single mothers}

In the US, $13 \%$ of the population consists of single parents and $85 \%$ of these are mothers (http://census.gov/population 2000). Twenty-eight percent of California households with children have incomes $125 \%$ of federal poverty level; approximately one out of five children in single mother households live below the poverty line (http://www.cbpp.org/ 1999). Sixteen percent of the population in Russia are single parents and $98 \%$ of these are mothers. According to larskaia-Smirnova and Romanov (2001), "The proportion of the poor among single-mother families was 2.5 times that of the married couple's families" (202). Half of all single mothers in Russia live with their parents, adult siblings or adult relatives. Norway has not collected statistics on single parents since 1999 because it is thought that many are actually living with a partner in a committed relationship (Hutchinson 2001). In 1998, 22\% of Norwegians were single parents and $88 \%$ were mothers. In all three countries, the majority of single parents on public assistance are mothers. A certain degree of authority to set policy regarding single parents has been decentralized to geographic regions/local governments (e.g. benefit amount, level of means testing) in US, Russia and Norway.

\section{Role of the social worker}

The curriculum in university-based social work programs in Norway and the US is well developed with a long history (1950s in Norway and 1920s in the US). Interest in professional social work emerged in Russia in the 1990s in response to the changing economic and political conditions. In Norway $88 \%$ of social workers are employed in public agencies (Hutchinson et al. 2001: 122), while only 33\% are in the US (http://www.naswdc.org/). This is more difficult to calculate in Russia where the profession, along with the social welfare system is undergoing profound changes. At the time of the first phase of the study, less than $7 \%$ of employed social workers in Saratov had a degree in social work (larskaia-Smirnova 2001). The major employers in all three countries are social services, both public and NGOs. While social workers have living wages in Norway and the US, they are included in the "working poor" in Russia where their salary is often about $60 \%$ of subsistence minimum. This is one of the major factors for the low employment rates of degreed social workers in public assistance programs in Russia.

In all three countries, the focus of help provided to parents on public assistance includes an assessment at the individual level. This role is rarely filled by a professional social worker in the US nor is it defined as a professional role. These positions are seen as technical. In Russia, these same positions are intended to be filled by educated social workers, but few are due to low pay and poor working conditions (larskaia-Smirnova and Romanov 2004). In Norway, most of these positions are filled with degreed social workers, and it is considered a professional role. One of the variations in our study is the role of professional social workers. 
In Norway, it is the degreed social worker that belongs to the national union/professional organization and is employed in a position that includes an economic assessment. It was once the role of social workers in the US to assess economic need and administer funds as part of their overall professional position, but a division was made several decades ago. "Eligibility" workers now do the assessment to determine if a mother qualifies for assistance.

Only in Norway are social workers mandated to do "preventive work" by national welfare policy (Social Services Act), "The social services shall acquaint themselves with living conditions in the municipality, pay special attention to aspects of its development which may create or prolong social problems...shall seek to provide suitable conditions for the development and strengthening of social ties and solidarity in the local community" (Lyngstad, et.al 2004:8). No such mandate exists in either the US or Russia; in fact, social workers in the US are frequently discouraged by supervisors and administrators from advocating for structural changes, even though advocacy and social change are a part of their professional code of ethics. "Solidarity" with clients would not be found in any public legislation that addresses poverty in the US or Russia, as it does in Norwegian social policy. Policies and procedures in social welfare call for social workers in all three countries to conduct assessments, based on national and/or regional policy guidelines for eligibility. Social workers in Russia and Norway have more flexibility than in the US where grant levels are pre-determined at the state level based on a mother's current assets. This kind of flexibility can either aggravate or support single mothers, as is mentioned in several conversations.

The commonality of the social workers in this study is that they all worked with single mothers on public assistance as part of their caseload. For some, this included a means test and for others it did not. Some of the social workers in the study worked in NGOs and others in public agencies. Regardless the context, the social workers were aware of the role economics played in their clients' lives, and in some instances, their own lives.

\section{Methodology}

A qualitative was chosen for the study, using an interview format. The questions were developed collaboratively among the researchers during meetings in Norway and via electronic mail. There were two interview sessions-one between the client and her social worker, and the second between the researcher and social worker. Both sets of interviews were audio-recorded, transcribed, translated into English when necessary and made available to all research partners. The interview between the social worker and her client consisted of fourteen questions about the mother's experience and perceptions of being poor and as a recipient of public assistance/social work services. The interview between the researcher and social worker consisted of four themes related to poverty and a fifth theme on the social worker's personal theoretical framework. The research group agreed that each researcher would develop the specifics of how the interviews would be conducted, given the cultural and political differences among the countries. These ranged from open-ended dialogues to more structured interviews.

Interview transcripts were analyzed by the researcher in each country, culminating in reports that highlighted particular themes and insights into poverty, the role and ethics of the social worker, public assistance and social welfare services. The data in this article relies on the final reports submitted by each researcher; these reports consisted of direct quotes from social workers and their clients, as well as paraphrasing and summaries from analysis of the transcripts. There is no intention to generalize any of the findings; rather it is hoped that the research gives voice to some of the experiences and perspectives of the participants in this study.

\section{Sample}


The participants live in Humboldt County in the US, Nordland "fylke" (county) in Norway and in Saratov, Russia. Demographics describing each region were from census reports of 1999 and 2000. Humboldt County is along the northern coast of California with a population of 128,000 , two small cities and a large rural area. Interviews took place in the city of Eureka, the county seat with approximately 25,000 inhabitants. Nordland lies along the northern coast of Norway, 50 miles above the Arctic Circle and has a population a little over 239,000. Municipalities in Nordland where studies took place ranged in population from 5,000 to 20,000 inhabitants. Saratov has a population of 2.7 million. Studies in Saratov took place in the main city and in a small town in the Saratov region, Krasnoarmeisk.

The sample was one of convenience, based on the home base of each researcher. Agency context was limited to those agencies that were open to allowing their workers to participate. For example, in Humboldt the public welfare agency did not grant permission to the social worker that wanted to be a part of the research, so an NGO that serves a similar population was contacted. In Saratov, the researcher had difficulty finding social workers with degrees who also had three years working in the agency which was a requirement of the study; so they decided to meet with those with the degree even if it meant less experience. All of the interviews are included in the researcher's reports and referenced in this article. There is no attempt to draw on a portion of the overall sample.

Social workers in this sample had a bachelors or graduate degree in social work (Table 2). Those participating in Nordland and Saratov worked in public agencies. The two social workers from Humboldt were employed in NGOs. There were a total of nine social workers participating-two each from Humboldt and Saratov, and five from Nordland. The majority of professional social workers in all three countries are female; in this sample, there was one male.

Table 2: Social Worker sample

\begin{tabular}{|l|l|l|l|}
\hline \multicolumn{1}{|c|}{ Social worker/age } & \multicolumn{1}{c|}{ Education/year } & \multicolumn{1}{c|}{ Employer } & \multicolumn{1}{c|}{ Clients served } \\
\hline Humboldt & BA S.W./1997 & NGO Alcohol/drug & Women in recovery \\
\hline Debbie/Female/29 & BA \& MSW/1994 & NGO Families & Families \\
\hline Liz/Female/46 & BA Child Welfare*/1996 & Public welfare office & Families \\
\hline Nordland & BA S.W./1990 & Public welfare office & Families \\
\hline na/Female/32 & BA S.W./1970 & Public welfare office & Families \\
\hline na/Female/42 & BA Child Welfare/1999 & Public welfare office & Families \\
\hline na/Male/56 & BA S.W./1990 & Public welfare office & Families \\
\hline na/Female/28 & \multicolumn{5}{l}{} \\
\hline na/Female & na & Public social services & Women/children \\
\hline Saratov & BA in S.W./na & Center social services & Women/children \\
\hline Svete/Female/23 &
\end{tabular}

Source: Lyngstad et al. (eds.) 2004

*Bachelors social work curriculum with a specialty in child welfare. na=not available

The client sample consisted of single mothers on public assistance who had at least one child under the age of ten years. "Single mothers" is defined as a mother of children living on her own due to divorce, death, separation, choice or abandonment. There were 17 mothers who participated in the conversations with their social workers - two in Humboldt, five in Nordland and ten in Saratov. 
The client sample (Table 3) was selected by each of the social workers participating in the study for diverse reasons. According to the social workers, the choices they made ranged from such things as mothers that were articulate, that had voiced concerns about services or benefits, that made significant progress in their lives, and/or that had a "good" rapport with them.

Table 2: Social Worker sample

\begin{tabular}{|c|c|c|}
\hline Mother's age/Children & Education & Living situation \\
\hline \multicolumn{3}{|l|}{ Humboldt } \\
\hline Hope/29/3 ( $2<10$ yrs \& 1 preteen) & No diploma & Hotel room for 9 months \\
\hline Leah/29/3 <10 yrs & No diploma & Subsidized flat \\
\hline \multicolumn{3}{|l|}{ Nordland } \\
\hline Siri/25/1 (4 yrs) & Finished school & Subsidized flat \\
\hline Wenche/32/1 (5 yrs) & Finished school & Subsidized flat \\
\hline Torunn/31/2 (8 \& 11 yrs) & Finished school & Subsidized flat \\
\hline Lina/35/2 (4 \& 5 yrs) & Finished school & Subsidized flat \\
\hline Monica/45/5 ( $5 \& 10$ yrs, 1 teen \& 2 adult children & Finished school & Subsidized flat \\
\hline \multicolumn{3}{|l|}{ Saratov } \\
\hline Maria/30/2 (ages na) & Secondary & Flat w/parents \\
\hline Nina/40 /na & Higher education & Social refuge w/mother \\
\hline Katia/43/1 & Higher education & Flat w/parents \\
\hline Irina/27/2 & na & Rents a flat \\
\hline Zoia/36/2 & Vocational Ed & Rents a flat \\
\hline Natalia/32/1 & Vocational Ed & House w/parents \\
\hline Marina/36/1 & Higher education & Hostel \\
\hline Liubov/40/3 & Vocational Ed & Hostel \\
\hline Larissa/35/2 & Vocational Ed & Rents a flat \\
\hline Tatiana/43/1 & Vocational Ed & Lives w/mother \\
\hline
\end{tabular}

Source: Lyngstad et al. (eds.) 2004

na $=$ not available

\section{Emergent themes}

In this study, we were most interested in finding out about agency and community, as opposed to individual barriers. When the women do speak about personal obstacles, it is in relation to the consequences of being a client in the welfare system; for example, shame as an effect of a mother's interaction with welfare workers and/or the system itself. I will address three dominant themes from the interviews that capture some of the concerns expressed by the mothers and social workers-- meager public benefit levels, the shame of being poor, and a sense of hopelessness-women have while being on welfare. Quotes from the mothers and social workers in the US and Russia are more dominant in the following sections. This reflects findings as presented in the project reports rather than any intent on my part to privilege some realities more than others.

Inadequate support: "Do you call 70 rubles a benefit?"

Mothers and social workers agree that the grant for single parents is insufficient to meet monthly expenses. While resources to meet basic needs (e.g. safe and affordable housing, health care, child care, food, access to higher education and livable wages) are more available in Norway, they are less available in the US or Russia.

In Norway, mothers express concern about rising debt from borrowing and their children not having what other school age or "normal" children have, like leisure activities and equipment so 
they could take part in recreation programs like other children. In Russia and the US, clients struggle with basic needs-- not being able to pay utility bills, rent, childcare, and food. Marina in Russia urges,

"....at least enlarge the size of the benefit. The prices are growing, the benefits are not. And some privileges to get a place in kindergarten could be provided so that I could have work and get the child cared for. I have minimal salary, I work in a kindergarten but cannot get my child there" (Iarskaia-Smirnova and Romanov, 2004: 236).

A mother asks, "Do you call seventy rubbles a benefit?" (Iarskaia-Smirnova and Romanov, 2004: 231). Liubov, a single mother from Saratov says,

"Children should be provided [a] free place in summer camp. Previously in Soviet Union this was so. And now my children even do not get free meals at school. All these should be fought for. And I have neither forces, nor time" (247).

Many talked about the importance of knowing about resources and how to have access to them. Mothers identify NGOs as playing a role in humanitarian aid, but that the resources are not always available there either, as Zoia and Irina describe. Zoia says,

"They [another family] have received [humanitarian] help from Germany. ...one kilo of rice, sunflower oil, some grains, pasta, [washing] powder, [...]l have applied to all possible placesit occurred that I was not on that list! [They said it was] given to the very needy and I was not in their number. I felt very hurt then" (Iarskaia-Smirnova and Romanov, 2004:223).

Irina also confronted obstacles to getting NGO resources, "We ourselves do not go there and never learn about what's happening, and they do not come and say. Could they send us messages, at least..." (larskaia-Smirnova and Romanov, 2004:223). Even if resources are available, a mother might be rejected, as a mother in Saratov shares, “Well, maybe I don't know some of my rights. Maybe I should apply... Well, I applied with money issue, but they said they cannot help with money" (235). Leah who lives in the US where NGOs play a significant role in the social welfare system and that access to resources is vital if her family is to survive,

"There are all kinds of programs out there. You just need to know where to go and who to ask... I start thinking of any possible way that I can come up with something... I borrow money; I turn in cans; I go to the food bank; I go to Free Meals twice a week and get bread... Sometimes I get embarrassed that I have to go down there [food bank], but it's free" (Brown, 2004:300).

Even when trying to obtain shelter, access is an issue. Subsidized rentals in the US and Russia are an example. There are typically long waiting periods for subsidized housing, which can be as long as a six-month wait in the county where Hope and Leah live. When Hope completed a recovery program, and was ready to be discharged, the only option for her was a motel, and that would consume most of her monthly income. At the time of the study, she had been living in a one-room motel with her three children for nine months without a kitchen. Leah on the other hand, is able to receive public housing assistance. "If I did not get Section 8 [subsidized rent], I would not make it...l'm very lucky" (Brown, 2004:299). The situation is somewhat different in Russia, where housing is not available, resulting in half of single mothers being forced to live with other family members (larskaia-Smirnova and Romanov 2004).

In addition to the inadequate benefit levels and lack of access to resources, regulations that stipulate reduction in already meager benefits further aggravate a mother's ability to cover expenses, as shared by two social workers in Norway:

"Many times when I am making these decisions using the guiding norms, I'm thinking, 'How can people manage, how can they survive and how can they keep sane?'...And also that every time they try to do something, when they have been on social security benefits for many years and then they get a trainee job or a casual job and they get income, then we withdraw money, right? They never get anything extra. The motivation is immediately taken away from them. 
And that makes me so furious. No matter what they achieve, we'll manage to withdraw it" (Lyngstad, et al. 2004:52).

Leah describes another way the system lacks policies and regulations that could motivate people, but that in the end, have the opposite effect:

"... not helping you change so that you can make a better living. Wanting to go to college, they're saying no [...] we want you to do this job training so you can go out and work [...] They're just getting you stuck in dead-end jobs [...] the wages are not high enough [...] Lots of people go to college and get support [...] but people who are low income, who are poor, they get sanctioned when they go to school. [...]They should let us educate ourselves so that we can take care of our families...let us get an education without taking our money away" (Brown 2004:301).

As to who shoulders the responsibility for inadequate benefit levels, lack of resources, and punitive rather than empowering policies and regulations, it is the elected officials and department staff who are responsible. Some mothers pointed out that the social worker is at the mercy of politicians who set the norms and standards. Nordland social workers in the study do believe that the regionally-set norms they are required to use in their assessments are inadequate, even though the regulations provide only "guidelines" and assessments are individualized. Clients "are not angry at the social workers when they reject her applications, but rather the politicians. ...social workers do their job as best they can and that they often find it painful to turn down applications" (Lyngstad, et.al., 2004:26). One mother's experience as summarized by the researcher,

"She thinks the help given is like keeping her stuck in 'a bog'. Social welfare benefit keeps your head over the water but does not drag you out. Line [client] says she understands the social workers are just using the norms decided by the politicians and she thinks they really want to help their clients more than they actually do (25)."

Debbie adds her perspective on the lack of understanding about poverty on the part of policy makers,

"They [policy makers] don't understand how difficult it is. What is it really like to make a choice between PG \& E [utilities] and eating dinner? How do you find the right idea? You can get a free meal in town, so you should pay your PG\&E. Well, I don't know what it's like to have to get a meal and listen to a church service that is not my religion, or I don't want to take my family down and have dinner for two hours" (Brown, 2004:309).

A worthy life: "I am pauper..."

The social workers and mothers in the Russia sample specified that their clients are "paupers", not just poor, but destitute. However, in the professional context of public social services, the term "poverty" is not used but instead "maloobespechennyi" i.e. low income. Social workers in Saratov many times are in a similar economic situation as their clients. The salary of social workers in Russia is about $60 \%$ of subsistence minimum, and they are in a category called “...'the working poor', i.e. people whose wages do not provide a subsistence minimum sum" (larskaia-Smirnova and Romanov 2004:224). The relationship between social worker and client can be impacted by similar economic circumstances. As a social worker in Saratov describes,

"...sometimes it happens so, that clients come, demand help, while the employees say, 'we have nothing to eat, we did not get salary in time, our salary is less than yours, we need help ourselves, while we should come to you to provide assistance for you. What do you demand?'" (larskaia-Smirnova and Romanov 2004:224.)

This is a unique circumstance, not one found in the US or Norway where the economic and social systems are much more stable and have a longer history. Workers in the US that are 
employed in positions to help economically disenfranchised families (e.g. homeless, working full time at wages below poverty level, unemployed) or child care programs earn much lower incomes than other workers (e.g. garbage collectors, plumbers), but their wages more often than not are above poverty level.

In Norway when the mothers talked about poverty, it was relative to other families, as Marina describes, "Especially when [I] go out to some big cities, I consider my family as an absolutely pauper. In many ways one should reject the needs." The mothers in Norway vary in their responses to a question on being poor; some see themselves as poor, but others do not. Regardless, all of the mothers in the study talk of feelings related to shame and embarrassment about their economic and social status. Zoia expresses a similar feeling in Russia,

"I am pauper. I am not poor. I am pauper, [it is] real destitution. [Look] how other children are going to school, all they are so elegant. While we... I have only one pair of shoes, both to work and at home and everywhere I wear them. 'ceremonial walking out', one pair."

The social workers in Humboldt both talked about how being poor contributes to a mother's shame and stereotypical attitudes on the part of the public about people who are poor. The following example is about how poverty makes one more visible and vulnerable to discrimination,

"...I mean in reality if you are poor and have an addiction, you are doubly shamed, you know. If you are middle class and you have a cocaine problem, it is not seen the same. ... The child welfare service isn't going to be involved with the family. There is a different level of capability there, it seems. ...I think that we are much more judgmental of the poor addicted person than we are of addiction in different classes" (Brown 2004:314).

A sense of shame about being poor and on public assistance is a dominant theme expressed, which is aggravated when one has a drug addiction. Simply being a parent places a mother in a vulnerable position as well. This is more evident in the US and Russia than in Norway where children, parenting and family hold a high priority in the culture. There were three mothers who spoke about the discrimination and shame. According to Liubov,

"Some time ago I was registered at the employment office. I remember it very good. I was coming to a new job and as soon as they learned that I had two children, they immediately rejected. For instance, in PTU No 15 they told me: my children will get sick, I will take the leave, which is unprofitable for them. ...I tried to work at the market as a shop assistant. But if I work the whole day, my kids are abandoned" (Iarskaia-Smirnova and Romanov 2004:229).

Another mother in Saratov echos this. Larissa, says,

Last week my youngest, Stiopka, got ill. He is often ill. I have to send him to a kindergarten even though he had fever. I have no relatives in this town. ...I was almost fired in autumn. Nobody even looked at the fact that I raise two kids alone. It was so humiliating. My boss said to me, 'I did not make you deliver them' (230).

Maria who also lives in Saratov shares a similar experience, "...had a dream to stay [at this job]: unsuccessful because of children. Nobody will keep you if you need flexible scheme of working hours" (229).

Another contributing factor to the mother's sense of shame is the public perception that recipients of aid are unmotivated. Leah says that health and welfare workers often treat her with less dignity, and that she is aware of the stigma attached to being on aid, how society assumes she is lazy. Debbie points out how the lack of resources limited Hope's attempts to have a worthy life, in spite of her motivation to improve her situation. Hope completed her recovery program and was ready to make good decisions for her family,

"And now her family has been experiencing this for nine months. For an eleven year old 
to have that shame also...so she has to be this really independently strong person because she has to network her family through this semester and then deal with how her family is dealing with that" (Brown, 2004:319).

As one of the researchers in Russia explains, "As a result, the deficit of resources necessary to overcome life difficulties is not fulfilled and service user becomes a 'client' with the stigma of 'troublesome', helpless and useless" (larskaia-Smirnova and Romanov 2004:246). Clients and workers in Russia speak about social inequality, unequal access to needed resources, and the "deserving" and "undeserving" poor. According to Natalia,

"The child sees no fruits, but they bring us the same products as we buy ourselves-the cheapest, the worst. I know, they provide help for children with disabilities, from families of many children, while single mothers are forgotten" (226).

Sometimes a mother's economic need becomes less central to the assessment of her circumstances than personal or individual qualities. As Nina in Saratov says, "I am not that needy. As for psychologists and speech pathologists - we do not need them either... the assistance should be financial in the first place, right?" (246).

Loss of hope: "It felt like they were trying to drown me."

Many of the mothers talk about losing hope that life could be any better. Hope feels that, "Once you are on welfare it is going to start a cycle of depression that is pretty much unavoidable" (Brown 2004:295). ... "I'm trying to figure out what I want to do and I'm so busy trying to help the girls do what they want to and I'm always worried about what somebody else wants. It's hard to take time to breathe" (293). All of the mothers describe being in a constant state of worry and exhaustion, and afraid to think of the future.

One contributing factor to hopelessness is the amount of documentation required, like they are "under surveillance". Mothers in Norway have to write an application every third month for public assistance (after their entitled three years on the social insurance program ends). Each time a mother must retell her story and fill out more paperwork. The Norwegian researchers summarize Line's feeling that it is "impossible not to feel unworthy however the social worker meets the client. The feeling, she thinks, has to do with not managing yourself, being dependent on help you have to ask for and having somebody assess you" (Lyngstad, et.al., 2004:26), "...a sign you do not manage your life" (47). They face unending demands for verbal and written accountability for, what one mother in Saratov called, a "meager allowance". When a social worker in Russia asked if Irina felt the social services were helpful to her, she responded, "Well, yes. But what shall I say, they help, yes. But they write much more than they give, anyway" (Iarskaia-Smirnova and Romanov 2004:221).

Monika in Nordland saw little relevance in all of the "talk and talk" that is required (Lyngstad et al. 2004:27), and Venka did not like having to "tell so much about one's problems both financial and psychological ones" (20); Torunn echoes this, "Just like they are invading my privacy totally" (Lyngstad et al. 2004:23). Clients' reactions to being on the National Insurance Scheme are different than as a recipient of the SWO. As one Norwegian social worker describes it, "Here [SWO] you have to beg" (25).

Mothers in the US and Russia say that the sense of inadequacy and hopelessness can be aggravated by social workers. Hope talks about how one of her social workers encouraged her to just "settle" rather than reach for something more substantial in her life,

"...[She told me] that there's not much help for me ever becoming mentally stable and I should go flip burgers...It felt like they were trying to drown me. ...l see a lot of potential for failure, but the whole idea of not even trying is not something I can live with....There is no self-pride or self-confidence in that" (Brown 2004:295). 
Torunn and Marina both try to hold on to possibilities, as Marina says, "Hopefully I will be able to work...it's not only for the money, it also concerns how I feel about myself, about being useful, being useful for society quite simply. That's giving you more satisfaction" (Lyngstad 2004:23). Marina has lost hope,

"I gave up relying on the state long ago. [I hope] on my own optimism that I will always have power to work up. Or perhaps as Ivanushka-fool [Ivanushka-fool is a character from Russian tales who becomes rich and happy as a result of fairy helpers and mysteries]" (larskaia-Smirnova and Romanov 2004:235).

The social workers in all three countries are restricted by agency and government regulations to one degree or another; they are also limited by a inadequate social and economic resources, particularly in the US and Russia. Like their clients, they encounter a dead end when trying to find resources, and end up feeling defeated. The social worker, too, wonders if things can change. Social workers struggle deeply with what to do when there are no resources, as Hope's social worker says,

"I just think that the social worker is tired of seeing folks struggle or dealing with poverty and not having solutions. I think that's really hard to be a social worker and be like 'I don't know how you're gonna move out of the motel. I don't know how you're gonna get from step $A$ to $B "$ (Brown 2004:316).

\section{Summary}

Mothers in all three countries describe feeling inadequate and to blame for being poor and on public assistance. The social welfare system is often stigmatizing for the mothers and, in some situations aggravated by stereotypes and discrimination. The relationships women have with their social workers vary, but not so much among the countries as within each country. The quality and type of relationship is affected by such things as the amount of documentation, degree of required personal disclosure, type of support, and the social worker's assessment. Social workers and clients alike voiced the opinion that the benefits are inadequate to meet a family's needs. The difference in destitution emerge between the US and Russia, as compared with Norway. Meeting needs such as housing, food and health care were commonly identified by mothers and social workers in the US and Russia, as contrasted with Norway where they spoke more often of rising debt and capacity to give their children what other families have. These experiences mirror the differing welfare philosophies. Women in Norway where poverty is defined in relative terms describe feeling poor compared to other families. The mothers in the US and Russia tend to speak more about lack of resources to meet basic needs, which reflects poverty as an absolute, based on a subsistence level of support.

\section{Implications}

Mothers and social workers both describe the social welfare system as generally oppressive. For clients in the system, they talk of feeling ashamed and unworthy. How do social workers respond to the oppressive conditions and lack of adequate resources? How do they deal with the obvious contradiction in their professional role that ethically mandates their first responsibility is to their client? Where do they find a balance between this and their integrity as an employee in the social welfare system of private and public services? Lastly, how do they grapple with the authority they do have?

Hopelessness: "...I have nothing for you..."

As the women and their social workers in the US and Russia describe, more often than not they face situations where minimal to no resources are available. And yet, they are the link for women to public services, resources, providers, community leaders and a supportive peer system (McPhee \& Bronstein (2003). In his rich and graphic portrayal of three families on 
welfare in Milwaukee, DeParle (2004) writes about a caseworker in the welfare department, "'You're lied to on a constant basis,' he said. But sometimes he felt he was lying, too, talking up the promise in all these dead-end jobs" (253). Workers are intent on motivating their clients, encouraging them to have faith that opportunities are there. They do this knowing that the odds are often not in their favor.

So how do the social workers in this study describe their perspective in situations where nothing concrete can be given? A couple social workers spoke to this. Iarskaia-Smirnova and Romanov (2004) describe what one Russian social worker does,

"One of the informants while giving a characteristic of strategies in social work has emphasized a policy of avoiding complex issues in making a diagnosis of a problem.... the worker says "... prefer not to 'dig' specially because they are afraid of 'digging out' something unsolvable..." (245-6).

On the one hand, this seems ethical, as it defines the role within the constraints of the institution and what the social worker can and cannot deliver. "Digging out something unsolvable" can expose a client's vulnerability in a context where there is nothing to give, and as noted in previous sections, some of the mothers in Norway resented this .

Debbie describes still seeing potential, when there are no resources; it is in the potential of the human connection. She believes that the relationship might be a sustaining force to get people through the rough spots until concrete assistance can be arranged. She says her mentor when she was a student helped her find a way to deal with this,

"She showed me how to be patient, enduring and not always there with a solution, [...] even though they [clients] don't leave with anything physically in their hands or solutions but be empowered by sharing their experience. [...]And that was our philosophy. I began working in a walk-in shelter house, in resource and referral. And people would come in homeless looking for a hotel for the night. I had two for the whole county. So often I had 15 families. Thirteen of them I would have to say 'I have nothing for you' and I'd have to decide which two would get the rooms. So it was this whole 'How do I make sense of that, and how do I make it so that someone comes back?' and it's that whole gift of 'let's talk about what's going on, and we don't have anything to give you. I have no more vouchers. I have no more blankets. I have nothing to give to you, other than you can have some time and talk to me about that experience and some of your options.' And I did that for a year, and that's really hard... And so the reason why people come back is because they know they are going to be respected, they know that they are going to have some time. Sometimes that is just all we need. Not that it's all we need, but it feels good to be able to say 'I'm having a really bad day and I want things to be different, damn it'; just to have someone else to express that to" (Brown 2004:316, 323).

The caseworker in DeParle's study that resigned at one point for a variety of reasons, including the lack of concrete help and the maladaptive ways that clients adjust to this reality. He returned because "He decided he might be good at the job and that the job might do some good. Casework requires a balance between inspiration and caution, hope and reality..." (255). It would seem that this balance is of utmost importance at times when the social worker has nothing to give. Being present to hear a client's story and affirm their feelings may help to instill a sense of hope through the relationship that conditions can change; this assumes that a social worker has the time and capacity for such presence. DeParle (2004) doubts that this kind of time and relationship is common in most agencies, "The promise of individualized casework... is more extraordinary than it sounds. Personalized attention, if it ever existed, was chased from the system two generations ago" (254). 
Authority: "And here you are really facing a dilemma."

Social workers in all three countries describe their lack of power to work for institutional and societal change that could improve resources for mothers and their children. The degree of autonomy to make policy or social change varies among the three countries. According to Lyngstad, et al. (2004), social workers in Norway have considerable autonomy if they used it (van Wormer 1994). In fact, Norway is the only country with a national public policy that mandates social workers to ..."seek to provide suitable conditions for the development and strengthening of social ties and solidarity in the local community" (Lyngstad, et al., 2004:8). In spite of the mandate, researchers in Norway find that social workers are as likely to internalize agency norms and culture as social workers do elsewhere. Therefore, social workers often face this dilemma to help families in an organizational context that is invested in denying or limiting help. One of the consequences in Norway is that some "...social workers think they are paying out their own money" (Lyngstad et al. 2004:59). This dilemma is particularly profound in the US and Russia when resources are drying up and little is to be found in the way of concrete help.

larskaia-Smirnova and Romanov (2004) identify the historical legacy and current challenges in Russia,

... However, given 70 years of Soviet era when social protection was highly centralized and bureaucratized, the organizational cultures of the new social services sometimes reproduce old patterns of bureaucracy, especially where employees lack professional education (172). Very often a social worker's responsibility in practical setting is considered as preventing a client from getting a service or a benefit for which this client is eligible (251).

In spite of the authoritative and impersonal environment in the departments where they are employed, individual social workers feel empathy and respond accordingly. Masha works in a formal state bureaucracy in Russia,

And here you are really facing a dilemma-we provide them with help but [they, i.e. client] would drink this money out and the child will get nothing anyway, but when one visits them to write an inspection act, looks into their eyes-it is hard (larskaia-Smirnova and Romanov 2004:225).

Social workers and clients in this study try to find meaning in the relationship, but the more rigid and formal context can thwart their efforts. In Seccombe's study (1999), mothers repeatedly talked about how "impersonal" the system was and that more "one-on-one help" was needed (166). The women want social workers who demonstrate compassion and who facilitate help (Pearlmutter \& Bartle, 2000), not as gatekeepers or agents of the welfare system.

To counter the organizational rigidity, some social workers in Russia have tried to change the work milieu by creating a more "home-like environment and friend-type relationship with clients" (larskaia-Smirnova and Romanov, 2004). Examples are that they give their home phone numbers, acknowledge birthdays, and decorate with "green plants, flowers, calendars with pussy-cats, photographs of pop stars and relatives" (199). These attempts meet with mixed reviews according to the researcher partners in Russia.

On the positive side, such changes potentially reduce barriers and contribute to more compassionate and personal relationships with clients. Some of the clients see their worker like a friend. Leah describes her social worker in the US as a significant part of her support network to help her become independent, "I tell my friends that I love my social workers, they are like my family. I need people like that, I need support to help me..." (Brown 2004:301).

Nina also describes a relationship with her social worker in Russia that she valued, "It happened so that I came in and sat at her table at once. And when she began asking me 
about my problems, about everything, about my current life, it occurred that I have a lot of different problems. And she arranged my things in their respective drawers and wrote down all this. It was so friendly and warm conversation, even to tears..." (Iarskaia-Smirnova and Romanov 2004:247).

There are also some risks when social workers are seen as or try to become a "friend". One risk is a less objective approach, compromising the professional nature of the role and the reality of the degree of authority that a social worker has. Another concern is that the relationship dynamics in the social worker's family end up being duplicated in their intervention with clients, rather than based on professional ethics and sound practice theories (larskaia-Smirnova and Romanov 2004).

The struggle to find a balance between being an advocate for clients' needs and a representative of the agency is familiar to social workers in all three countries, in spite of differing codes of ethics, educational requirements, policy mandates and professional roles. This seeming contradiction in the profession of social work is not new and presents challenges in practice (Abramovitz 1998; Jones-DeWeever \& Gault 2006; Richan \& Mendolsohn 1974; Specht \& Courtney 1994). Social workers speak of having little to no authority to make policy or organizational recommendations that would help meet a client's economic needs. In spite of policy mandates in Norway, social workers feel they lack access to administrators and policy makers. The lack of any such public policy in the US or Russia limits the range of strategies that front line social workers can use, even though they are the professionals who are most aware of the unmet needs of mothers and children (Danziger et al. 1999; DeParle, 2004; Edin and Lein 1997; Scarbrough 2001; Seccombe 1999).

Swigowski (1996) argues that social workers need to join with welfare mothers as partners in understanding how the social welfare system disenfranchises both of them. "Today, it is imperative for social workers to find a professional occupational focus in public welfare because of connections between the changes in the welfare system and the focus groups participants' fears about the child welfare system, which has always been the province of social workers (Pearlmutter \& Bartle, 2000: 169).

\section{Final Thoughts}

One of the most surprising outcomes of this study was the common experience of clients and social workers, in spite of living and working in significantly different socio-political and cultural contexts. I did not expect the degree of commonality among social workers whose educational levels and curriculum vary. While social workers (BSW and MSW) in the US are not involved in the financial decisions about public assistance like the workers in Norway and Russia, the ramifications of the poverty in their clients' lives directly impacts their work. The understanding of shame and the importance of empathy and respect were evident in the workers' conversations. Equally important was the felt duality of their roles as advocates for change and agents of authority in a bureaucracy. They talked of an acute awareness of their client's struggle to make a different life. While this centered on such needs as affordable housing, livable wages, educational opportunities, safe child care in Russia and the US, the sense of urgency among mothers in Norway had more to do with equity and being able to provide for their children what other parents could.

Since the mothers and their social workers were not comparing conditions, policies or programs across national borders, we don't know how they might have responded. For example, if the mothers in Norway had information about the punitive welfare policies in the US, would their perspectives of their own circumstances change? Might the mothers in the US and Russia feel some sense of entitlement, as well as possibility, at the realization of the potential in social welfare to provide a better safety net if they learned about Norway? A study that includes 
sharing such information could illuminate a deeper reflection and analysis, a process that holds the potential to be empowering for women who are struggling with feelings of shame and a loss of self-efficacy (Gutierrez 1991; Maguire 1987).

In public policy research directed at the study of disenfranchised groups, it would be interesting to use a participatory approach (Finn, 1994; Hall, 1975; Maguire, 1987; Park et al. 1993; Tandon 1981). It is humbling to have the privilege of conducting research across national borders that brings attention to the disparities in how nations respond to social need; in this study, the poverty of single mothers with small children. Participatory research theory and approaches could engage the mothers as partners in designing a method where critical reflection brings attention to the historical and cultural underpinnings that support one social welfare system more generously than another. This focus transcends the individual and makes obvious how the broader social structure impacts peoples' lives. It also holds the promise of empowerment, "Proponents of participatory approaches to research understand that research produces knowledge and that knowledge is power" (Finn and Jacobson, 2003:331). For people who are struggling to have any sense of control over their lives, partnering with researchers can have a positive impact. Incorporating, rather than excluding, the mothers and social workers in the research design lends itself readily to mutual learning. Such an approach to study also brings to bear the more personal and empowering nature of relationships across different socio-economic statuses, something the mothers and social workers in this study find valuable with their social workers. Lastly, involving the participants holds the hope that they can be actors in policy evaluation. After all, it is most often social movements led by people affected that bring about broad social and institutional change. The women and their social workers in this study shared insights about some of what needs to be changed in the social welfare systems in these countries to better support them and their children.

\section{References}

Abramovitz, M. (1998): Social work and social reform: An arena of struggle, Social Work, Vole 43 No. 6, pp 512-527.

Abramovitz, M. (1988): Regulating the Lives of Women: Social Welfare Policy from Colonial Times to the Present. Boston, MA: South End press.

Arias, D. C. (2007): Federal report examines links between poverty, health access, Nation's Health, Vol. 37 No. 2, March p 7.

Baker, M. (2002) When flexibility meets rigidity: sole mother's experiences in the transition from welfare to work, Journal of Sociology, Vol 38, No. 4 pp 345-360.

Brandwein, R.A. and Filiano, O.M. (2000): Toward real welfare reform: The voices of battered women. Affilia, Vol 15 No. 2 pp 224-243.

Brown, P. (2004): Single mothers, poverty and social work: A case study from U.S. In (Eds.) R. Lyngstad, R., Hutchinson, S.G., Lund, L. and Oltedal, S. Single Mothers, Poverty and Social Work: Case Studies from Norway, Australia, Canada, Russia and USA, HBO rapport 8 , Høgskolen i Bodø

Brown, P. (2001) Social work in USA In (Eds) Hutchinson, G., Lund, L., Lyngstad, R. and Oltedal, S. (Eds.) (2001) Social Work in Five Countries: Professional, Educational and Social Policy Context for Social Work in Australia, Canada, Norway, Russia and USA, pp 211-262. HBO-rapport 25, Høgskolen i Bodø, Norway.

California Budget Project (2007) Independent analysis to improve the lives of low- and middle- 
income Californians, www.cbp.org.

Corcoran, M., Danziger, A., Kalil, A. \& Seefeldt, K.S. (2000): How welfare is affecting women's work. Annual Review of Sociology, Vol 26, pp 241-69.

Danziger, S, Corcoran, M., Danziger, S., Heflin, C., Kalil, A., Levine, J., Rosen, D., Seefeldt, K. Siefert, K. and Toman, R. (1999: Barriers to the employment of welfare recipients, Discussion Papers DP\# 1193-99, Institute o Research on Poverty, University of Wisconsin-Madison.

Danziger, S. and Gottschalk, P. (1995): America Unequal. Cambridge, MA: Harvard University Press.

Dinerman, M. and Faulkner, A.O. (Eds.) (2000): Affilia, Special Issue "Women and the new American welfare" Vol 15 No. 2.

Edin, K. and Lein, L.A. (1997): Making Ends Meet: How Single Mothers Survive Welfare and Low-Wage Work, New York: Russell Sage Foundation.

Esping-Andersen, G. (1990): The Three Worlds of Welfare Capitalism, Cambridge, MA: Princeton University Press.

Ferrer-i-Carbonell, A., Van Praag, B. (2001): Poverty in Russia, Journal of Happiness Studies, June 2001, Vol. 2 No. 2 pp147-172.

Finn, J.L. and Jacobson, M. (2003). Just Practice: A Social Justice Approach to Social Work. Peosta, lowa: eddie bowers publishing.

Finn, J. (1994). The promise of participatory research. Journal of Progressive Human Services Vol. 5, pp 25-42.

Fisher, G.M. (1992): The development of Orshansky poverty thresholds and the subsequent history as the official U.S. poverty measure. Poverty measures studies and alternative measures. http://www.census.gov/hhes/www/povmeas/papers/orshansky.htmld

Government Accounting Office (1997): Poverty measurement: Issues in revising and updating the official definition. Report to the Ranking Minority Member, Committee on Finance, U.S. Senate pp 1-48.

Gordon, L. (1994): Pitied But Not Entitled: Single Mothers and the History of Welfare. Cambridge: Harvard University Press

Gordon, L. (1988): Heroes of their Own Lives: The Politics and History of Family Violence. New York: Viking Penguin Inc.

Gutierrez, L.M. (1991): Developing methods to empower Latinos: the importance of groups. Social Work with Groups, Vol 14 No. 2 pp 23-43.

Haper, K. (2001): Stereotypes, childcare and social change: how the failure to provide childcare perpetuates the public perception of welfare mothers, Journal of Legislation and Public Policy, Vol 4 No. 2 pp 387-414.

Fisher, G.M. (1992): Poverty Measurement Working Papers: The Development of the Orshansky Poverty Thresholds and Their Subsequent History as the Official U.S. Poverty Measure, U.S. Census Bureau. 
Hall, B. (1975). Participatory research: An approach for change, Convergence Vol 8, No. 2, pp 24-32.

Hutchinson, G., Lund, L., Lyngstad, R. and Oltedal, S. (Eds.) (2001) Social Work in Five Countries: Professional, Educational and Social Policy Context for Social Work in Australia, Canada, Norway, Russia and USA, HBO-rapport 25, Høgskolen i Bodø, Norway.

Jennings, P. K. (2004): What mothers want: welfare reform and maternal desire, Journal of sociology and social Welfare, Vol 31 No. 3 pp 113-130.

Jones-DeWeever, A.A. and Gault, B. (2006): Resilient and Reaching for More: Challenges and Benefits of Higher Education for Welfare Participants and their Children, Publication No. D466, Washington D.C.: Institute for Women's Policy Research pp1-53.

Kohlert, N. (1989): Welfare Reform: A Historical Consensus, Social Work, Vol 34 No. 4 pp 303-306.

Lindhorst, T. and Mancoske, R.J. (2006): The Social and Economic Impact of Sanctions and Time Limits on Recipients of Temporary Assistance to Needy Families. Journal of Sociology and Social Welfare, Vol 33 No. 1 pp 93-114.

McIntyre, L., Officer, S., Robinson, L.M. (2003): Feeling poor: the felt experience of lowincome lone mothers. Affilia, Vol 18, No. 3, pp 316-331.

larskaia-Smirnova, E. and Romanov (2004) Social work in Russia, pp 159-210 In (Eds) Lyngstad, R., Hutchinson, G., Lund, L. and Oltedal, S. (Eds.) (2004) Single Mothers, Poverty and Social Work: Case studies from Norway, Australia, Canada, Russia and U.S. HBO-rapport 8, Høgskolen i Bodø: Norway.

Lyngstad, R., Hutchinson, G., Lund, L. and Oltedal, S. (Eds.) (2004) Single mothers, poverty and social work: Case studies from Norway, Australia, Canada, Russia and U.S. HBO-rapport 8, Høgskolen i Bodø: Norway.

Maguire, P. (1987): Doing participatory research: A feminist approach. Amherst: University of Massachusetts.

McIntyre, L., Officer, S. and Robinson, L.M. (2003): Feeling poor: The felt experience of lowincome lone mothers. Affilia, Vol 18 No. 3 pp 316-331.

McPhee, D.M. \& Bronstein, L.R. (2003): The journey from welfare to work: Learning from women living in poverty. Affilia, Vol 18, No. 1, pp 34-48.

Millar, J. (2001): Work-related activity requirements and labour market programmes for lone parents. In Millar, J. and Rollingson, K. (Eds.) (2001). Lone Parents, Employment and Social Policy: Cross National Comparisons. pp. 189-210. Bristol, UK: The Policy Press.

Millar, J. and Rollingson, K. (Eds.) (2001). Lone Parents, Employment and Social Policy: Cross National Comparisons. Bristol, UK: The Policy Press.

Nicolas, G. and JeanBaptiste, V. (2001): Experiences of women on public assistance. Journal of Social Issues, Vol 57 No. 2 pp 299-310.

Park, P., Brydon-Miller, M., Hall, B. and Jackson, T. (Eds) (1993): Voices of Change, Westport: 
Bergin and Garvey.

Pearlmutter, S. and Bartle, E.E. (2000): Supporting the move from welfare to work: what women say, Affilia, Vol 15 No. 2, pp 153-172.

Popple, P.R. and Leighninger, L. (2005): Social Work, Social Welfare and American Society Boston: Pearson.

Rainford, W.C. (2004): Paternalistic regulation of women: Exploring punitive sanctions in temporary assistance to Needy Families, Affilia Vol 19 No. 3 pp 289-304.

Richan, W. and Mendolsohn, A.R. (1973): Social work: The unloved profession, New York: New Viewpoints.

Scarbrough, J.W. (2001): Welfare mother's reflections on personal responsibility. Journal of Social Issues, Vol 57, No. 2, pp 261-276.

Scott, J. (2006): Job satisfaction among TANF leavers, Journal of Sociology and Social Welfare, Vol 33 No. 3 pp 127-149.

Seccombe, K.,.Hartley, H., Newsom, J., Hoffman, K., Marchand, G., Albo, C., Gordon, C., Zaback, T., Lockwood, R., and Pope, C. (2007): The Aftermath of Welfare Reform Journal of Family Issues, Vol 28 No. 1 pp 151-181.

Seccombe, K. (1999): "So You Think I Drive a Cadillac?": Welfare Recipients' Perspectives on the System and its Reform. Boston, MA: Allyn and Bacon.

Seccombe, K., James, D. \& Walters, K.B. (1998): "They think you ain't much of nothing": the social construction of the welfare mother. Journal of Marriage and the Family, Vol 60 No. 4 pp 849-865.

Spade, M. (1994): Poverty measures mask the depth of poverty in America. Clearinghouse Review, Washington D.C.: National Consumer Law Center pp 517-524.

Specht, H. and Courtney, M.E. (1994): Unfaithful Angels: How Social work Has Abandoned its Mission, New York: NY: The Free Press.

Swigowski, M.E. (1996): Women, poverty and welfare reform: A challenge to social workers. Affilia Vol 11, No. 1 pp 95-110.

Tandon, R. (1981): Participatory research in the empowerment of people. Convergence, Vol 16 No. 3 pp 5-15.

Tickamyer, A.R., Henderson, D.A., White, J.A. and Tadlock, B.L. (2000): Voices of welfare reform: Bureaucratic rationality versus the perceptions of welfare participants. Affilia, Vol 15 No. 2, pp 173-192.

U.S. Census Bureau (1998) Poverty. http://www.census.gov/

van Wormer, K. (1994): A Society without Poverty--the Norwegian Experience, Social Work, Vol 39 No. 3 pp 324-327.

Wilensky, H. and Lebeau, C.H. (1975). The Welfare State and Equality. Berkeley: University of California Press. 
